\title{
PELAKSANAAN MANAJEMEN BERBASIS SEKOLAH (MBS) DI MTsN BATUSANGKAR
}

\author{
Misra dan Rika Maria \\ Dosen Fakultas Tarbiyah IAIN Imam Bonjol Padang \\ e-mail: misra_buya@ymail.com
}

\begin{abstract}
Target of which wish to be reached in this research is to depict execution of MBS in MTSN Batusangkar and explain its contribution to make-up of quality and quality education of madrasah and also explain supplementary factor and resistor met in its execution. Result of this research of meneggambarkan that execution of MBS in good enough MTSN Batusangkar. its Management system enough succeed to give contribution in improving student achievement and have appearance of good enough organization. As for supplementary factor in execution of MBS in MTSN Batusangkar besides society support and government which is high enough, also leadership which is kharismatik. While its resistor factor is student input which still lower, limitation of facilities and basic facilities learn which not yet adequate and also the source of fund from all less promising student old fellow
\end{abstract}

Key words: Execution, MBS.

\begin{abstract}
Abstrak: Tujuan yang ingin dicapai dalam penelitian ini adalah untuk menggambarkan pelaksanaan MBS di MTsN Batusangkar dan menjelaskan kontribusinya terhadap peningkatan kualitas dan mutu pendidikan madrasah serta menjelaskan faktor pendukung dan penghambat yang ditemui dalam pelaksanaannya.Hasil penelitian ini meneggambarkan bahwa pelaksanaan MBS di MTsN Batusangkar cukup baik. Sistem manajemennya cukup berhasil memberikan kontribusi dalam meningkatkan prestasi siswa dan memiliki penampilan organisasi yang cukup baik. Adapun faktor pendukung dalam pelaksanaan MBS di MTsN Batusangkar selain dukungan masyarakat dan pemerintah yang cukup tinggi, juga kepemimpinan yang kharismatik. Sedangkan faktor penghambatnya adalah input siswa yang masih rendah, keterbatasan sarana dan prasarana belajar yang belum memadai serta sumber dana dari para orang tua siswa yang kurang menjanjikan.
\end{abstract}

Kata kunci: Pelaksanaan, MBS.

\section{PENDAHULUAN}

Manajemen "madrasah" diartikan sebagai suatu proses sosial yang direncanakan untuk menjalin kerjasama, partisipasi dan keterlibatan orang lain dalam mencapai sasaran dan tujuan tertentu yang telah ditetapkan secara efektif. Manajemen mengandung unsur pembimbingan, pengerahan dan pengarahan sekelompok orang terhadap pencapaian tujuan secara umum. Manajemen juga diartikan memahami bagaimana sekelompok orang bisa bekerjasama secara sistematis. (Asnawir, 2006:25). Sebagai suatu proses sosial, manajemen "madrasah" harus meletakkan fungsi dan peranannya, dalam membangun interaksi orang-orang, baik yang berada di dalam maupun di luar lembaga formal "madrasah", atau yang berada di bawah maupun di atas posisi operasional seseorang dalam suatu organisasi "madrasah". (Tholkhah, 2004:30).

Madrasah dalam pertumbuhan sekaligus perkembangannya, memerlukan manajemen yang tepat. Karena manajemen merupakan aspek yang sangat krusial dan urgent dalam menentukan kesuksesan pencapaian tujuan sebuah lembaga madrasah. Menganalisa teori Manajemen, Islam telah mempunyai konsep tersendiri tentang manajemen. (Nawawi, 1993: 3). Apabila konsep tersebut dapat diimplementasikan menjadi suatu sistem manajemen yang sistematis, tepat, dan benar maka madrasah akan mencapai kesuksesan luar biasa, dalam menciptakan output peserta didik yang memiliki kematangan spritual, mental sekaligus penguasaan intelektual. 
Menyongsong era informasi yang semakin menantang ini, madrasah harus dikelola dengan sistem manajemen yang tepat dan jitu. Hal ini dilaksanakan agar madrasah mampu bersaing sekaligus mengikuti perkembangan zaman sesuai dengan kemajuan ilmu pengetahuan dan teknologi (Iptek) yang berlandaskan kepada moralitas yang Islami (Imtaq). Upaya penguasaan dan pengembangan (Iptek-Imtaq) ini adalah untuk mengaplikasikan fungsi manusia sebagai khalifah fil ardhi. Sejarah membuktikan bahwa dengan sistem manajemen yang tidak tepat dan tidak menyentuh akar permasalahan yang fundamental, hanya akan memperkeruh dan menambah problematika baru. Dalam versi lain dinyatakan bahwa kendala yang mengakibatkan rendahnya mutu madrasah saat ini, adalah lemahnya sumber daya dan dana, manajemen yang "asal" dan terbatasnya fasilitas dan saranaprasarana serta minimnya tenaga yang potensial. (Yunahar Ilyas, 1993:52). Untuk itu, madrasah sebagai sentral agen pendidikan Islam, sekaligus merupakan organisasi pendidikan keislaman, seyogyanya menjadi lokomotif pendidikan Islam terdepan yang perlu diurus dan dikelola secara tepat dan proporsional.

Sebuah tawaran yang perlu di respon semua pihak yang terlibat dalam pendidikan adalah pengelolaan madrasah dengan sistem Manajemen Berbasis Sekolah (MBS) atau Manajemen Berbasis Madrasah (MBM). Sistem ini menawarkan solusi dalam mempersiapkan siswa untuk lebih maju, karena sistem ini memberikan otonomi yang luas dan bertanggungjawab kepada madrasah, dan mendorongnya untuk melakukan pengambilan keputusan secara partisipatif untuk memenuhi kebutuhan mutu dan pencapaian tujuan madrasah. Otonomi sekolah/madrasah yang dimaksud adalah kewenangan sekolah untuk mengatur kepentingan warga sekolah sesuai dengan perundang-undangan nasional yang berlaku. Hal ini didasarkan pada undang-undang RI Nomor; 22 Tahun 1999 tentang otonomi daerah dan undang-undang RI Nomor: 20 Tahun 2003 tentang sistem pendidikan nasional. (UU RI No.20, 2005: Pasal 5 Ayat 1). Undang-undang ini membuktikan kesungguhan Pemerintah RI dalam upaya penyelenggaraan good govermance di bidang pendidikan. Hal ini merupakan wahana bagi usaha untuk memandirikan masyarakat sekolah dan madrasah untuk mengurus rumah tangganya sendiri.

Dipilihnya Manajemen Berbasis Sekolah untuk pendidikan dasar dan menengah, diyakini akan mempermudah pencapaian tujuan pendidikan yang baru. Ciri-ciri Manajemen Berbasis Sekolah adalah adanya otonomi yang kuat pada tingkat sekolah, peran serta aktif masyarakat dalam pendidikan, proses pengambilan keputusan yang demokratis dan berkeadilan, menjunjung tinggi akuntabilitas dan transparansi dalam setiap kegiatan pendidikan. Manajemen Berbasis Sekolah merupakan langkah awal peningkatan kualitas pendidikan melalui pendelegasian pengambilan keputusan dari pemerintah ke sekolah. Dengan Manajemen Berbasis Sekolah, diharapkan dapat meningkatkan efisiensi dan mutu penyelenggaraan pendidikan di madrasah agar menjadi lebih fokus dan terencana dengan baik. (E. Mulyasa, 2002:13).

Pelaksanaan Manajemen Berbasis Sekolah di madrasah, dianggap penting dengan alasan: Pertama, dapat mendorong kreativitas kepala sekolah untuk mengelolah Madrasah menjadi lebih baik. Kedua, dapat lebih meningkatkan kepedulian masyarakat untuk ikut bertanggung jawab terhadap kinerja dan keberhasilan madrasah. Ketiga, dapat mengembangkan tugas pengelolaan madrasah tersebut menjadi tanggung jawab madrasah dan masyarakat, sesuai dengan paradigma baru tentang signifikansi keterlibatan masyarakat dalam pendidikan. Keempat, pembuatan keputusan dan kebijakan yang berkaitan langsung dengan madrasah dapat dilakukan oleh madrasah itu sendiri. Ini berarti madrasah diberi keleluasaan untuk mengelola sumber daya, sumber dana, sumber belajar, dan mengalokasikannya sesuai dengan prioritas kebutuhan madrasah, sehingga diharapkan dapat lebih tanggap terhadap kebutuhan warga madrasah dan masyarakat sekitanya. (Depag. RI, 2005:iv).

Tujuan utama Manajemen Berbasis Sekolah adalah untuk meningkatkan kinerja seluruh warga sekolah terutama agar dapat 
menjalin kerjasama "bahu-membahu" demi mendongkrak prestasi madrasah. Berbagai literatur menunjukkan adanya beberapa strategi untuk mencapai keberhasilan implementasi MBS, strategi-strategi tersebut adalah:

1. Sekolah harus memiliki otonomi terhadap empat hal yaitu dimilikinya kekuasaan dan kewenangan, pengembangan pengetahuan yang berkesinambungan, akses informasi ke segala bagian dan pemberian penghargaan kepada setiap orang yang berhasil.

2. Adanya peran serta masyarakat secara aktif dalam hal pembiayaan, proses pengambilan keputusan terhadap kurikulum dan instruksional serta non-instruksional.

3. Adanya kepemimpinan kepala sekolah yang mampu menggerakkan dan mendayagunakan setiap sumberdaya sekolah secara efektif.

4. Adanya proses pengambilan keputusan yang demokratis dalam kehidupan dewan sekolah yang aktif.

5. Semua pihak harus memahami peran dan tanggungjawabnya secara sungguh-sungguh.

6. Adanya guidelines dari departemen terkait sehingga mampu mendorong proses pendidikan di sekolah secara efisien dan efektif. Guidelines itu jangan sampai berupa peraturan-peraturan yang mengekang dan membelenggu sekolah.

7. Sekolah harus memiliki transparansi dan akuntabilitas yang minimal diwujudkan dalam laporan pertanggungjawaban setiap tahunnya.

8. Penerapan MBS harus diarahkan untuk pencapaian kinerja sekolah dan lebih khusus lagi adalah meningkatkan pencapaian belajar siswa.

9. Implementasi diawali dengan sosialisasi dari konsep MBS, identifikasi peran masingmasing, mengadakan pelatihan-pelatihan terhadap peran barunya, implementasi pada proses pembelajaran, evaluasi atas pelaksanaan di lapangan dan dilakukan perbaikan-perbaikan. (E. Mulyasa, 2002:58).

Fokus masalah yang akan dibahas dalam penelitian ini adalah: bagaimana pelaksanaan Manajemen Berbasis Sekolah di MTsN
Batusangkar. Tujuan penelitian untuk mendeskripsikan Pelaksanaan Manajemen Berbasis Sekolah di MTsN Batusangkar dan menjelaskan kontribusinya terhadap peningkatan kualitas dan mutu pendidikan di MTsN Batusangkar serta mengetahui faktor pendukung dan penghambat pelaksanaannya.

Hasil penelitian secara khusus yang membahas tentang MBS sepanjang penelusuran yang dilakukan belum penulis temukan, apalagi pelaksanaannya di MTsN Batusangkar. Namun ada beberapa penelitian yang relevan dengan penelitian ini diantaranya.

Utoyo Dimyati misalnya, dalam penelitiannya tentang Manajemen Berbasis Sekolah dalam Upaya Peningkatan Mutu Madrasah (Studi Kasus di Madrasah Aliyah Banat NU Kudus),. Utoyo memberikan stressing pada persoalan bagaimana meningkatkan mutu sekolah melalui MBS dengan mengedepankan analisis SWOT sebagai acuannya. (Utoyo Dimyati, 2004).

Sama halnya dengan Sakdullah yang memberikan gambaran tentang upaya peningkatan mutu dan kualitas pendidikan, sabagaimana yang dipaparkan dalam penelitiannya tentang Konsep Strategi Pembelajaran di Madrasah Aliyah Al-Irsyad, Gajah, Kab. Demak . (Sakdullah, 2002). Akan tetapi Utoyo yang secara lebih eksplisit membahas tentang pengelolaan Madrasah Aliyah dalam perspektif MBS. Sementara Sakdullah mencoba menawarkan konsep tentang strategi pembelajaran di madrasah dengan menitik beratkan pada masalah kurikulum madrasah. Menurutnya, agar madrasah mampu bersaing dengan lembaga pendidikan lain dalam pengembangan ilmu dan teknologi maka madrasah harus mampu menerapkan kurikulum yang sesuai dengan kebutuhan masyarakat masa depan.

Lain halnya dengan Ainurrofiq, yang lebih menekankan terhadap fungsi-fungsi manajemen seperti: apa yang disebut dengan istilah POAC yaitu: perencanaan, pengorganisasian, penggerakan dan pengawasan atau pengendalian. Demikian diungkapkan dalam 
penelitiannya tentang Manajemen dalam Pendidikan Islam: Telaah atas Fungsi-fungsi manajemen. (Ainurrofiq, 1998:16).

Selanjutnya penelitian tentang Kebijakan Pemerintah Orba tentang Pendidikan Islam: Implikasinya terhadap Sistem Pendidikan Madrasah dan Pembaharuannya Pasca Orba, yang ditulis oleh Depi Asmal. Beliau mengemukakan gambaran dan paparan dari kebijakan pemerintah Orba tentang pendidikan Islam dan Implikasinya terhadap sistem pendidikan madrasah, baik sisi kelebihan maupun kekurangannya. Dengan cara ini, akan memunculkan pembaharuan oleh pemerintah Orba dengan berbagai kebijakan untuk peningkatan kualitas madrasah yang diharapkan dapat menjadi lembaga pendidikan prioritas masa depan. (Depi Asmal, 2003:10).

Dari beberapa hasil penelitian di atas, belum terlihat adanya suatu penelitian dan pengkajian yang mendalam tentang pelaksanaan Manajemen Berbasis Sekolah pada tingkat Madrasah Tsanawiyah Negeri (MTsN). Baik dalam bentuk penulisan, maupun penelitian ilmiah, maka penulis ingin mengkajinya lebih mendalam dalam bentuk penelitian.

Tujuan yang ingin dicapai adalah untuk menggambarkan pelaksanaan MBS di MTsN Batusangkar dan kontribusinya terhadap peningkatan kualitas dan mutu pendidikan madrasah, serta faktor pendukung dan penghambat yang ditemui dalam pelaksanaannya.

\section{METODE PENELITIAN}

\section{Teknik Pengumpulan Data}

a. Pengamatan (Observation), dilakukan terhadap manajemen pengelolaan Madrasah dan mengamati kegiatan pembelajaran. Observasi ini penulis lakukan kepada seluruh sumber data yang dibutuhkan.

b. Wawancara (Interview), pada awalnya dipakai wawancara tak berstruktur karena pertanyaan-pertanyaan belum spesifik. Kemudian dilanjutkan dengan wawancara berstruktur dengan pertanyaan-pertanyaan yang spesifik yang disusun berdasarkan apa yang telah disampaikan responden. (Nasution, 1988:72). Adapun pokok permasalahan dalam wawancara adalah masalah manajemen, PBM, SDM, sumber dana dan administarsi serta prestasi madrasah.Teknik ini, penulis gunakan kepada seluruh sumber data yang dibutuhkan.

c. Dokumentasi yaitu pengumpulan dan penulisan data yang berupa dokumen seperti: Struktur organisasi, keadaan siswa, guru, karyawan, daftar inventarisasi dan hasil prestasi kerja. Di dalam penelitian kualitatif data atau informasi dari dokumen termasuk non human resurces dapat dimanfaatkan dari data yang telah ada, siap pakai dan penggunaannya pun tanpa membutuhkan biaya. (S. Nasution, 1992:85).

\section{Metode Analisa Data}

Untuk menganalisa data yang bersifat kualitatif, akan dibuat kategorisasi berdasarkan masalah dan tujuan. Sehingga data tersebut mempunyai makna, di samping itu data diklasifikasikan menjadi dua kelompok yaitu data kualitatif dan kuantitatif, data kualitatif digambarkan dengan kata-kata atau kalimat untuk memperoleh kesimpulan, sedangkan data kuantitatif akan dijumlahkan diklasifikasikan sehingga merupakan urut data untuk selanjutnya dibuat tabel. (Arikunto, 1998:245-246).

Selanjutnya teknik analisis data dalam penelitian ini adalah deskriptif analitik, yaitu mendiskripsikan pelaksanaan MBS di MTsN Batusangkar, yang berkaitan dengan strategi pelaksanaannya, manajemen kesiswaannya, manajemen kurikulum dan program pengajarannya dan manajemen layanan khusus di MTsN Batusangkar.

\section{HASIL PENELITIAN}

\section{A. Pelaksanaan Manajemen Berbasis Sekolah di MTsN Batusangkar}

1. Kepemimpinan Kepala Sekolah 
Berikut disajikan data kuesioner yang disebarkan kepada 30 responden yang masuk 24 orang atau $80 \%$.

1) ketertiban siswa.

\begin{tabular}{c|c|c|c|c}
\hline \multirow{2}{*}{$\begin{array}{c}\text { Responden } \\
\text { (orang) }\end{array}$} & \multicolumn{4}{|c}{ Ketertiban Siswa } \\
\cline { 2 - 5 } & $\begin{array}{l}\text { Sangat } \\
\text { tertib }\end{array}$ & $\begin{array}{l}\text { Cukup } \\
\text { tertib }\end{array}$ & $\begin{array}{l}\text { Biasa } \\
\text { saja }\end{array}$ & $\begin{array}{l}\text { Kurang } \\
\text { Tertib }\end{array}$ \\
\hline 24 & 7 & 14 & 3 & - \\
\hline $100 \%$ & $29,17 \%$ & $58,33 \%$ & $12,50 \%$ & - \\
\hline
\end{tabular}

2) penyebab ketertiban siswa

\begin{tabular}{c|c|c|c|c}
\hline \multirow{2}{*}{$\begin{array}{c}\text { Responden } \\
\text { (orang) }\end{array}$} & \multicolumn{4}{|c}{ Penyebab ketertiban Siswa } \\
\cline { 2 - 5 } & $\begin{array}{l}\text { Kerja } \\
\text { sama }\end{array}$ & $\begin{array}{l}\text { Ketega- } \\
\text { san KS }\end{array}$ & Guru & Siswa \\
\hline 24 & 11 & 6 & 6 & 1 \\
\hline $100 \%$ & $45,83 \%$ & $25 \%$ & $25 \%$ & $4,67 \%$ \\
\hline
\end{tabular}

3) prestasi siswa

\begin{tabular}{|c|c|c|c|c|}
\hline \multirow[b]{2}{*}{$\begin{array}{l}\text { Jumlah } \\
\text { Responden } \\
\text { (orang) }\end{array}$} & \multicolumn{4}{|c|}{ Penyebab Prestasi Siswa } \\
\hline & $\begin{array}{l}\text { Manajemen } \\
\text { yang baik }\end{array}$ & $\begin{array}{l}\text { Keter- } \\
\text { tiban } \\
\text { guru }\end{array}$ & $\begin{array}{l}\text { Tamba- } \\
\text { han } \\
\text { pelajaran }\end{array}$ & Siswa \\
\hline 24 & 12 & 8 & 3 & 1 \\
\hline $100 \%$ & $50 \%$ & $33,33 \%$ & $12,50 \%$ & $4,67 \%$ \\
\hline
\end{tabular}

4) usulan staf

\begin{tabular}{c|c|c|c|c}
\hline \multirow{2}{*}{$\begin{array}{c}\text { Responden } \\
\text { (orang) }\end{array}$} & \multicolumn{4}{|c}{ Respon pimpinan terhadap usulan staf } \\
\cline { 2 - 5 } & $\begin{array}{l}\text { Selalu } \\
\text { diterima }\end{array}$ & $\begin{array}{l}\text { Kadang } \\
\text { diterima }\end{array}$ & $\begin{array}{l}\text { Diterima } \\
\text { dengan } \\
\text { catatan }\end{array}$ & $\begin{array}{l}\text { Tidak } \\
\text { diteri } \\
\text { ma }\end{array}$ \\
\hline 24 & 7 & 14 & 3 & - \\
\hline $100 \%$ & $29,17 \%$ & $58,33 \%$ & $12,50 \%$ & - \\
\hline
\end{tabular}

5) pelaksanaan program-program madrasah

\begin{tabular}{c|c|l|l|l}
\hline \multirow{2}{*}{$\begin{array}{c}\text { Responden } \\
\text { (orang) }\end{array}$} & \multicolumn{4}{|c}{ Pelaksanaan program-program sekolah } \\
\cline { 2 - 5 } & $\begin{array}{l}\text { Dilaksa } \\
\text { nakan } \\
\text { dengan } \\
\text { baik }\end{array}$ & $\begin{array}{l}\text { Dilaksana } \\
\text { kan } \\
\text { kurang } \\
\text { serius }\end{array}$ & $\begin{array}{l}\text { Dilaksana } \\
\text { kan } \\
\text { sebagian }\end{array}$ & $\begin{array}{l}\text { Tidak } \\
\text { dilaksana- } \\
\text { kan }\end{array}$ \\
\hline 24 & 16 & 5 & 3 & - \\
\hline
\end{tabular}

\begin{tabular}{c|c|c|c|c}
\hline $100 \%$ & $66,66 \%$ & $20,83 \%$ & $12,50 \%$ & - \\
\hline
\end{tabular}

\section{Hubungan Kerjasama Madrasah}

Hubungan kerjasama ini meliputi kerjasama yang bersifat intern madrasah dan hubungan yang dijalin dengan masyarakat luas.

a. Hubungan intern Madrasah

Data-data yang berkaitan dengan kerjasama intern madrasah dapat dilihat pada uraian job discription di depan. Sedangkan untuk pelaksanaan job discription tersebut, dapat dilihat dari hasil penyebaran koesioner sebagai berikut:

1) kepuasan kerja.

\begin{tabular}{c|c|c|l|c}
\hline \multirow{2}{*}{$\begin{array}{c}\text { Responden } \\
\text { (orang) }\end{array}$} & \multicolumn{4}{|c}{ Kepuasan kerja karyawan } \\
\cline { 2 - 5 } & $\begin{array}{l}\text { Sangat } \\
\text { senang }\end{array}$ & Senang & $\begin{array}{l}\text { Biasa } \\
\text { saja }\end{array}$ & Terpaksa \\
\hline 24 & 7 & 15 & 2 & - \\
\hline $100 \%$ & $29,17 \%$ & $62,50 \%$ & $8,33 \%$ & - \\
\hline
\end{tabular}

2) penyebab kepuasan kerja.

\begin{tabular}{c|c|c|c|c}
\hline \multirow{2}{*}{$\begin{array}{c}\text { Responden } \\
\text { (orang) }\end{array}$} & \multicolumn{4}{|c}{ Penyebab kepuasan kerja karyawan } \\
\cline { 2 - 5 } & Kerja sama & $\begin{array}{l}\text { Teman } \\
\text { kerja }\end{array}$ & Bakat & $\begin{array}{l}\text { Kesejahtera } \\
\text { an }\end{array}$ \\
\hline 24 & 7 & 5 & 3 & 14 \\
\hline $100 \%$ & $29,17 \%$ & $20,83 \%$ & $12,50 \%$ & $58,33 \%$ \\
\hline
\end{tabular}

b. Hubungan Ekstern Madrasah

Berdasarkan data-data yang diperoleh, bahwa MTsN Batusangkar berhasil menjalin hubungan kerjasama dengan masyarakat luas. Baik hubungan itu berkenaan dengan kepentingan pengembangan sarana maupun prasarana madrasah maupun untuk kepentingan pengembangan kemampuan guru serta keterampilan siswa.

Untuk urusan membantu madrasah dalam kerjasama dengan masyarakat dibantu sebuah badan yang disebut dengan komite sekolah MTSN Batusangkar.

Tugas Komite Madrasah adalah: 
1. Mendorong timbulnya perhatian dan komitmen masyarakat terhadap penyelenggaraan pendidikan yang bermutu

2. Melakukan kerjasama dengan masyarakat (dunia usaha dan Home Industry) dan pemerintahan berkenaan dengan penyelenggaraan pendidikan

3. Mendorong orang tua siswa dan masyarakat berpartisapi dalam pendidikan guna mendukung peningkatan mutu dan pemerataan pendidikan

4. Menggali dana masyarakat untuk pembiayaan madrasah

5. Memberikan masukan pertimbangan dan rekomendasi kepada madrasah mengenai:

a. Kebijakan dan program

b. RAPBM

c. Kriteria kinerja

d. Kriteria fasilitas

e. Hal-hal yang terkait dengan pendidikan

6. Melakukan evaluasi dan pengawasan terhadap kebijakan program penyelenggaraan madrasah

\section{Proses Pembuatan Keputusan}

Pembuatan keputusan di madrasah adalah melalui musyawarah, sehingga keputusan yang dihasilkan merupakan hasil pemikiran bersama sedangkan pada jenjang pelaksanaan segala keputusan tersebut didelegasikan kepada penanggungjawab masing-masing bidang. Kepala madrasah bertugas sebagai motivator, koordinator dan supervisor serta evaluator. Apabila terdapat persoalan-persoalan baru dalam pelaksanaan diagendakan dan dibahas kemudian pada musyawarah berikutnya.

Dalam hal yang sifatnya harus memerlukan penyelesaian mendesak, kepala madrasah membuat kebijakan dengan mengacu kepada program yang sudah ada. (Wawancara, 22 Juni 2008).

Sebagai pelengkap berikut disajikan beberapa hasil koesioner berkaitan dengan proses pengambilan keputusan yang dilakukan sekolah utamanya kepala sekolah.
1) frekuensi rapat lengkap.

\begin{tabular}{c|c|c|c|c}
\hline \multirow{2}{*}{$\begin{array}{c}\text { Responden } \\
\text { (orang) }\end{array}$} & \multicolumn{4}{|c}{ Frekuensi Rapat Lengkap } \\
\cline { 2 - 5 } & $\begin{array}{l}\text { Setiap } \\
\text { bulan }\end{array}$ & $3-4$ bulan & 1 Smter & 1 Tahun \\
\hline 24 & - & 22 & 2 & - \\
\hline $100 \%$ & - & $91,67 \%$ & $8,33 \%$ & - \\
\hline
\end{tabular}

2) rapat khusus pimpinan dan wali kelas

\begin{tabular}{c|c|c|c}
\hline \multirow{2}{*}{$\begin{array}{c}\text { Responden } \\
\text { (orang) }\end{array}$} & \multicolumn{3}{|c}{ Frekuensi Rapat dengan Wali Kelas } \\
\cline { 2 - 4 } & $\begin{array}{l}\text { Setiap } \\
\text { minggu }\end{array}$ & Setiap bulan & $\begin{array}{l}\text { Setiap } \\
\text { Smstr/lebih }\end{array}$ \\
\hline 24 & - & 23 & 1 \\
\hline $100 \%$ & - & $95,83 \%$ & $4,17 \%$ \\
\hline 3) $\begin{array}{l}\text { partisipasi guru/karyawan } \\
\text { memberikan pendapat }\end{array}$
\end{tabular}

\begin{tabular}{c|c|c|c|c}
\hline \multirow{2}{*}{$\begin{array}{c}\text { Responden } \\
\text { (orang) }\end{array}$} & \multicolumn{4}{|c}{ Frekuensi Pendapat Guru/ Karyawan } \\
\cline { 2 - 5 } & $\begin{array}{c}\text { Setiap } \\
\text { Rapat }\end{array}$ & Sering & $\begin{array}{l}\text { Kadang- } \\
\text { kadang }\end{array}$ & $\begin{array}{l}\text { Tidak } \\
\text { Pernah }\end{array}$ \\
\hline 24 & 4 & 7 & 12 & 1 \\
\hline $100 \%$ & $16,67 \%$ & $29,17 \%$ & $50 \%$ & $4,17 \%$ \\
\hline
\end{tabular}

4) respon pimpinan terhadap pendapat guru/ karyawan

\begin{tabular}{|c|c|c|c|c|}
\hline \multirow{2}{*}{$\begin{array}{l}\text { Responde } \\
\text { n (orang) }\end{array}$} & \multicolumn{4}{|c|}{$\begin{array}{l}\text { Respon Pimpinan terhadap pendapat guru/ } \\
\text { karyawan }\end{array}$} \\
\hline & $\begin{array}{l}\text { Selalu } \\
\text { diterima }\end{array}$ & $\begin{array}{l}\text { Kadang- } \\
\text { kadang }\end{array}$ & $\begin{array}{l}\text { Diterima } \\
\text { sebagai } \\
\text { catatan }\end{array}$ & $\begin{array}{l}\text { Tidak } \\
\text { diterima }\end{array}$ \\
\hline 24 & 5 & 17 & 2 & - \\
\hline $100 \%$ & $20,83 \%$ & $70,83 \%$ & $8,33 \%$ & - \\
\hline
\end{tabular}

5) pemberian saran/ ususl kepada pimpinan oleh guru/ karyawan

\begin{tabular}{c|c|c|c|c}
\hline \multirow{2}{*}{$\begin{array}{c}\text { Responden } \\
\text { (orang) }\end{array}$} & \multicolumn{4}{|l}{ Pemberian saran/usul dari guru/ karyawan } \\
\cline { 2 - 5 } & Sering & $\begin{array}{l}\text { Kadang- } \\
\text { kadang }\end{array}$ & $\begin{array}{l}\text { Sekedar } \\
\text { basa-basi }\end{array}$ & $\begin{array}{l}\text { Tidak } \\
\text { pernah }\end{array}$ \\
\hline 24 & 6 & 13 & - & 5 \\
\hline
\end{tabular}




\begin{tabular}{|c|c|c|c|c|}
\hline $100 \%$ & $25 \%$ & $54,67 \%$ & - & $20,83 \%$ \\
\hline \multicolumn{5}{|c|}{$\begin{array}{l}\text { 6) pengambilan keputusan oleh } \\
\text { tanpa musyawarah }\end{array}$} \\
\hline \multirow[b]{2}{*}{$\begin{array}{l}\text { Responden } \\
\text { (orang) }\end{array}$} & \multicolumn{4}{|c|}{ Pengambilan Keputusan tanpa Musyawarah } \\
\hline & Sering & $\begin{array}{l}\text { Kadang- } \\
\text { kadang }\end{array}$ & $\begin{array}{l}\text { Pernah } \\
\text { satu/dua } \\
\text { kali }\end{array}$ & $\begin{array}{l}\text { Tidak } \\
\text { pernah }\end{array}$ \\
\hline 24 & 2 & 8 & 4 & 9 \\
\hline $100 \%$ & $8,33 \%$ & $33,33 \%$ & $16,67 \%$ & $37,5 \%$ \\
\hline
\end{tabular}

\section{Transparansi Manajemen}

Berkenaan dengan persoalan ini, hasil interview menunjukkan data yang kurang lebih sama dengan angket yaitu sebagian besar mengatakan tahu sebagian kecil mengatakan tahu sedikit. Adapun tentang hasil koesioner berkaitan tentang hal tersebut adalah sebagai berikut:

1) asal sumber dana madrasah

\begin{tabular}{c|c|c|c|c}
\hline \multirow{2}{*}{$\begin{array}{c}\text { Responden } \\
\text { (orang) }\end{array}$} & \multicolumn{4}{|c}{ Asal Sumber Dana Madrasah } \\
\cline { 2 - 5 } & $\begin{array}{c}\text { Tahu } \\
\text { Detail }\end{array}$ & $\begin{array}{c}\text { Tahu } \\
\text { Global }\end{array}$ & $\begin{array}{c}\text { Tahu } \\
\text { sedikit }\end{array}$ & $\begin{array}{c}\text { Tidak } \\
\text { tahu }\end{array}$ \\
\hline 24 & 11 & 12 & 1 & - \\
\hline $100 \%$ & $45,83 \%$ & $50 \%$ & $4,17 \%$ & - \\
\hline
\end{tabular}

2) alokasi dana madrasah

\begin{tabular}{c|c|c|l|c}
\hline \multirow{2}{*}{$\begin{array}{c}\text { Responden } \\
\text { (orang) }\end{array}$} & \multicolumn{4}{|c}{ Alokasi Dana Madrasah } \\
\cline { 2 - 5 } & $\begin{array}{l}\text { Tahu } \\
\text { Detail }\end{array}$ & $\begin{array}{l}\text { Tahu } \\
\text { Global }\end{array}$ & $\begin{array}{l}\text { Tahu } \\
\text { Sedikit }\end{array}$ & Tidak Tahu \\
\hline 24 & 3 & 12 & 8 & 1 \\
\hline $100 \%$ & $12,5 \%$ & $50 \%$ & $33,33 \%$ & $4,17 \%$ \\
\hline
\end{tabular}

\section{B. Faktor Pendukung dan Penghambat Pelaksanaan MBS di MTsN Batusangkar}

\section{Faktor Pendukung Pelaksanaan MBS}

Proses pelaksanaan MBS diperlukan berbagai dukungan dari semua pihak, agar pelaksanaannya dapat berjalan sesuai dengan harapan. Adapun faktor-faktor pendukung pelaksanaan MBS di MTsN Batusangkar adalah:

a. Bidang Kepemimpinan Kepala Sekolah

1) Sebagai kepala sekolah, dalam kepemimpinannya cukup berwibawa dan kharismatik sehingga dalam memotivasi, mengawasi dan mengendalikan para staf tidak begitu sulit

2) Dalam membuat rencana kerja dan keputusan senantiasa didahului dengan musyawarah bersama bawahan

3) Pendapatan pengalokasian dana operasional sekolah dianggap cukup transparan

4) Hubungan dengan komite sekolah terjalin sangat baik dan komunikatif

5) Kemampuan berkolaborasi dengan guru dan masyarakat sekitarnya tidak diragukan. (Wawancara, 24 September 2008).

b. Bidang Krikulum

Kurikulum yang dipakai adalah kurikulum KBK dan KTSP yang ditambah dengan muatan lokal dengan memadukan sistem pembelajaran pesantren.

c. Bidang Personalia

1) Semangat dan pengorbanan yang tinggi dari para staf dalam mengelola sekolah

2) Kerapian dalam melaksanakan tugastugas administrasi.

d. Sarana, Prasarana dan Media Pembelajaran

Kebutuhan terhadap sarana dan prasarana serta media pembelajaran telah terpenuhi meskipun hanya sebatas kebutuhan dasar.

\section{e. Lingkungan Masyarakat}

Berkaitan dengan lingkungan masyarakat, MTsN Batusangkar sangat terlihat kondusif apalagi lokasi sekolah yang sangat strategis di tengah-tengah lingkungan masyarakat yang agamis, ditambah pula dukungan yang kuat dari masyarakat lingkungan semacam 
bantuan sarana dan prasarana sekolah yang ada. (Wawancara, 14 September 2008).

\section{Faktor Penghambat Pelaksanaan MBS}

Selain beberapa faktor pendukung tersebut, ada juga beberapa faktor yang menjadi kendala atau penghambat pelaksanaan MBS di MTsN Batusangkar diantaranya adalah:

a. Bidang Kepemimpinan Kepala Sekolah

1) Memimpin sekolah masih terkesan monoton dalam artian kurang berkembang

2) Kemampuan manajerial masih rendah

3) Kemampuan pengembangan sekolah untuk jangka panjang masih kurang.

b. Bidang Kurikulum

Untuk kurikulum nasional (KBK dan KTSP) sering terjadinya pergantian GBPP sedangkan untuk kurikulum muatan lokal tidak tersedianya GBPP sehigga pembelajaran terkesan sangat monoton. (Wawancara, 13 September 2008).

c. Bidang Personalia

1) Minimnya jumlah staf dalam pengelolaan sekolah sehingga pekerjaan sering menumpuk

2) Belum mampu memberikan penghargaan yang layak

3) Belum terwujud pembinaan staf secara berkala.

d. Sarana, Prasarana dan Media Pembelajaran

Kurang menjaga perawatan sarana dan prasarana sekolah serta media pembelajaran yang ada.

e. Lingkungan Masyarakat

1) Warga masyarakat utamanya para orang tua siswa yang mayoritas berpendidikan rendah sehingga kontrol terhadap anakanaknya kurang

2) Adanya krisis ekonomi yang tidak kunjung pulih yang mengakibatkan berkurangnya partisipasi masyarakat terhadap sekolah. (Wawancara, 15 September 2008).
Untuk menganalisa manajemen MTsN Batusangkar yang berkenaan dengan pelaksanaan MBS akan dikelompokkan dalam empat bagian sesuai dengan komponen MBS yaitu, manajemen, proses pembelajaran, sumber daya manusia serta sumber dana dan administrasi.

\section{Manajemen}

Dalam bidang manajemen ini ada enam indikator yang harus dipenuhi sesuai dengan karakteristik MBS yaitu:

a. Manajemen/organisasi kepemimpinan kepala sekolah

b. Menyusun rencana dan merumuskan kebijakan sekolah

c. Mengelola operasional sekolah

d. Adanya komunikasi yang efektif antara sekolah dan masyarakat terkait

e. Mendorong partisipasi masyarakat dan

f. Menjamin akan terpeliharanya sekolah yang bertanggungjawab (accountability). (Team Teknis, t.t...).

Indikator-indikator tersebut, dapat dilihat pada struktur organisasi, job description, rencana pengembangan, komite madrasah, intensitas rapat, data alumni dan data supervisi dan dilengkapi dengan hasi angket yang berkenaan dengan kepemimpinan kepala sekolah.

Sesuai dengan data yang diperoleh di lapangan, enam indikator yang ada tersebut sebagian besar telah dipenuhi meskipun masih ada kekurangan di sana-sini. Hal ini tercermin dari job descriptions yang telah dibuat oleh kepala sekolah dan juga rencana pengembangan yang dituangkan dalam RIP MTsN Batusangkar.

Berkenaan dengan bentuk kerjasama yang dikembangkan oleh kepala sekolah dengan komite madrasah telah berhasil mengadakan komunikasi yang efektif dengan instansi terkait, masyarakat, alumni serta mampu mendorong masyarakat untuk berpartisipasi 
dalam pembelajaran dan pengembangan fisik madrasah. Angket-angket yang masuk sebanyak 24 orang atau $80 \%$ dari 30 responden yang diharapkan, ini dapat memperkuat data di lapangan.

Angket yang berkenaan dengan ketertiban siswa menunjukkan bahwa madrasah tersebut cukup tertib, terbukti bahwa dari 24 responden, 14 orang diantaranya mengatakan cukup tertib atau 58\%. Sebagian yang lain mengatakan sangat tertib 29\%, 12,50\% mengatakan biasa-biasa saja dan tak seorangpun yang ada mengatakan tidak tertib. Demikian pula halnya hasil angket juga menunjukkan bahwa penyebab ketertiban siswa adalah karena manajemen yang baik. Hal itu terlihat dari data bahwa $45,83 \%$ responden mengatakan bahwa penyebab ketertiban siswa adalah berkat kerjasama antara kepala sekolah, guru, karyawan serta siswa itu sendiri. Di samping faktor pendukung yang lain seperti ketegasan kepala sekolah $25 \%$, peran serta guru $25 \%$ serta tumbuhnya kedesiplinan dari siswa itu sendiri 4,67\%. Apabila dicermati dengan baik bahwa penyebab kedesiplinan siswa ini, selain dari beberapa faktor tersebut juga tidak lepas dari faktor kepemimpinan.

Demikian juga tentang prestasi siswa di MTsN Batusangkar terwujud karena manajemen yang baik yang dikembangkan oleh sekolah. Meskipun prestasi yang diraih saat ini belum begitu banyak akan tetapi dukungan utama prestasi siswa tersebut adalah berkat sistem manajemen yang baik dari sekolah. Hal ini sesuai dengan hasil angket yaitu $50 \%$ responden mengatakan demikian, $12,40 \%$ karena faktor ketertiban guru dan tambahan pelajaran yang diberikan di luar sekolah dan 4,67\% mengatakan karena faktor intern dari siswa itu sendiri.

Adapun angket yang berkaitan dengan respon pimpinan terhadap usulan staf pengajar, diperoleh hasil bahwa $58,33 \%$ mengatakan kadang-kadang usulan diterima, 29,17\% mengatakan selalu diterima dan yang mengatakan usulan diterima dengan catatan hanya $12,50 \%$ serta tak satupun ada staf pengajar yang mengatakan usulan tidak diterima. Dengan demikian dapat disimpulkan bahwa dalam kepemimpinan seorang kepala sekolah senantiasa merespon berbagai persoalan yang disampaikan oleh bawahannya.

Sedangkan data yang berhubungan dengan pelaksanaan programprogram sekolah menunjukkan $66,66 \%$ mengatakan baik, 20,83\% mengatakan kurang serius dan $12,50 \%$ mengatakan dilaksanakan sebagian serta tak seorangpun yang mengatakan bahwa program-program sekolah tidak dilaksanakan. Hal ini mengindikasikan bahwa program-program yang telah disepakati dalam rapat diupayakan untuk dilaksanakan dengan baik meskipun karena sesuatu hal program tersebut belum dapat dilaksanakan.

Selanjutnya data lain yang berkenaan dengan kepemimpinan adalah kerjasama secara intern madrasah yaitu berkenaan dengan keadaan para staf dalam menjalankan tugas-tugasnya. Keadaan ini berkaitan dengan kesenangan bekerja yang dilakukan oleh para staf dalam menjalankan aktivitasnya di madrasah. Ternyata di MTsN Batusangkar dengan kepemimpinan yang baik para staf merasakan kepuasan dalam bekerja. $62,50 \%$ mengatakan senang, 29,17\% mengatakan sangat senang dan $8,33 \%$ lainnya mengatakan biasa-biasa saja serta tak seorangpun yang mengatakan bekerja dengan terpaksa. Adapun penyebab kesenangan dan kepuasan mereka dalam bekerja adalah karena adanya kesejahteraan yang diberikan oleh sekolah cukup memadai untuk kebutuhan hidup. Hal ini terbukti bahwa $58,33 \%$ responden 
mengatakan hal demikian di samping adanya kerjasama yang baik $29,17 \%$. Maka hal ini dapat disimpulkan bahwa MTsN Batusangkar telah dapat memberikan kesejahteraan yang cukup kepada karyawannya sehingga mereka semangat dalam bekerja di samping juga ada beberapa faktor pendukung laiinnya seperti kerjasama yang harmonis dan teman kerja yang menyenangkan juga karena bakat yang dimiliki oleh para staf yang ada.

Akan halnya transparansi pimpinan dalam mengelola madrasah sesuai data yang diperoleh berkaitan dengan sumber dana, semua staf mengetahui asal sumber dana madrasah. Hal ini terlihat dari hasil angket yang terbanyak dengan $50 \%$ responden mengetahuinya secara global, 45,83\% mengetahuinya secara detail dan hanya 4,17\% yang sedikit mengetahui serta tak satupun yang mengatakan tidak mengetahui sama sekali. Hanya saja merupakan suatu kelemahan, bahwa tidak semua bawahan dapat mengetahui alokasi dana yang telah diperoleh tersebut. Ini dapat dibuktikan dengan hasil angket bahwa ada $4,17 \%$ tidak mengetahuinya, selebihnya antara $33,33 \%$ s/d $50 \%$ dapat mengetahuinya secara global dan mengetahui sedikit. Dari data tersebut dapat disimpulkan bahwa MTsN Batusangkar dalam kepemimpinannya sekaitan dengan sumber dana dan pengalokasiannya masih belum sepenuhnya transparansi.

\section{Proses Belajar Mengajar}

Untuk komponen pembelajaran ada empat indikator yang harus dipenuhi dalam pengelolaan sekolah yang dapat dikategorikan sebagai sekolah dengan manajemen berbasis sekolah. Empat indikator tersebut adalah:

a. Mempromosikan belajar siswa

b. Menyusun kurikulum yang cocok dan tanggap terhadap semua kebutuhan siswa

c. Menawarkan pembelajaran yang efektif d. Menyediakan pengembangan pribadi siswa. (Team Teknis, t.t...).

Data tentang proses pembelajaran ini dapat dilihat pada frekuensi kehadiran siswa, guru dan karyawan, kurikulum yang ditawarkan, jurusan yang tersedia, MGMP guru, program ekstra kurikuler, rata-rata prestasi lulusan, penanganan lulusan, ketersediaan sarana dan prasarana yang berkenaan dengan praktikum, keterampilan dan perpustakaan, minat baca siswa dan kiat pembinaan siswa.

Frekuensi kehadiran siswa di MTsN Batusangkar ternyata cukup tinggi, rata-rata mencapai $97 \%$ meskipun pada dua tahun sebelumnya sempat mendekati rata-rata $98 \%$. Kondisi seperti itu menunjukkan adanya minat siswa yang tinggi untuk mengikuti pembelajaran atau paling tidak merupakan kepatuhan siswa terhadap aturan yang telah ditetapkan oleh madrasah. Dan juga dengan keaktifan siswa, madrasah mengupayakan kualitas belajar bagi siswanya. Kenyataan itu juga ditunjang oleh frekuensi MGMP yang terealisir sekitar $80 \%$ dari rencana yang ditetapkan.

Sedangkan dari sisi kurikulum MTsN Batusangkar berusaha merespon kebutuhan siswa, ini terbuk ti dengan adanya kurikulum tambahan seperti muatan lokal dan kegiatan ekstra kurikuler serta berbagai keterampilan dan ilmu-ilmu keagamaan yang cukup sehingga setelah mereka menamatkan sekolah mereka tinggal pilih ingin melanjutkan ke SMA atau MAN.

Data kehadiran guru yang diperoleh ternyata diluar dugaan yaitu rata-rata $97 \%$ dan dari data guru yang ada $76 \%$ diantaranya sarjana S.1 pada bidangnya. Selanjutnya untuk pengembangan siswa dapat dilihat pada penawaran kegiatan ekstra kurikuler yang cukup padat untuk merespon perkembangan zaman diantaranya adalah kursus komputer, bahasa (arab dan inggris), olahraga, kesenian, menjahit, kaligrafi dan seni baca alquran. Hal ini dapat dibuktikan dengan adanya prestasi siswa yang diraih pada even-even berbagai perlombaan baik pendidikan maupun keagamaan. 
Dengan demikian untuk komponen PBM, maka MTsN Batusangkar dapat dikatakan memenuhi kriteria MBS relatif cukup baik. Hanya saja yang perlu ada peningkatan adalah minat baca siswa yang masih sangat rendah dan perlu ditingkatkan. Karena dalam kurun 3 tahun terakhir minat baca siswa senderung menurun.

\section{Sumber Daya Manusia (SDM)}

Sumber daya manusia merupakan komponen penting yang harus dipenuhi dalam kerangka MBS. Adapun indikator-indikator dalam sumber daya manusia adalah :

a. Menyebarkan staf dan menempatkan personil yang dapat memenuhi keperluan siswa

b. Memilih staf yang memiliki wawasan school based strategies

c. Menyediakan untuk mengembangkan profesi pada semua staf

d. Menjamin kesejahteraan staf dan siswa

e. Mengatur review/pembahasan penampilan sekolah (school performance)

Data yang berkenaan dengan indikatorindikator tersebut dapat dilihat pada job description, data guru dan karyawan, program pentgembangan madrasah, frekuensi rapat lengkap dan rapat khusus pimpian dan pelaksanaan MGMP madrasah.

Sesuai dengan data-data yang diperoleh bahwa pembagian tugas pada MTsN Batusangkar telah tersusun rapi hanya saja dari sekian banyak pembagian tugas yang diberikan kepada staf kemungkinan belum semuanya dapat dilaksanakan. Namun dalam setiap kesempatan program-program tersebut dievaluasi melalui rapat-rapat rutin dan juga dibahas melalui rapat-rapat khusus pimpinan. Menurut data yang ada dalam proses pembuatan keputusan menunjukkan bahwa sebagian besar responden atau $91,67 \%$ mengatakan rapat lengkap dilaksanakan setiap 3-4 bulan sekali dan 95,83\% mengatakan rapat khusus pimpinan dan wali kelas diadakan setiap satu bulan sekali. Di samping itu kepala sekolah masih sering minta pendapat masukan dan saran secara informal.

Data angket juga menunjukkan bahwa kepala madrasah mintak pendapat dan saran secara informal, dan yang mengatakan sering sebanyak $25 \%$, kadang-kadang $54,67 \%$ dan $20,83 \%$ mengatakan tidak pernah meminta pendapat seperti itu.

Berdasarkan data-data tersebut ternyata sebagian besar indikator-indikator yang berkenaan dengan sumber daya manusia telah terpenuhi meskipun jumlah tenaga guru yang dimiliki oleh MTsN Batusangkar belum mencukupi dibanding dengan jumlah siswa yang ada. Satu-satunya indikator yang belum terlaksana dengan baik adalah mengnai jumlah karyawan yang masih sangat terbatas meskipun kesejahteraan mereka cukup memadai. Akan tetapi dengan pekerjaan yang mungkin dapat dikatakan over lapping mengharuskan para karyawan kerja ekstra.

\section{Sumber Dana dan Administrasi}

Komponen ini adalah merupakan komponen yang sangat penting untuk dipenuhi bagi sekolah yang menerapkan MBS. Indikatorindikator yang harus dipenuhi dalam komponen sumber dana dan administrasi ini adalah:

a. Mengidentifikasi sumber dana yang diperlukan dan mengalokasinkannya sesuai dengan kebutuhan

b. Mengelola alokasi dana sekolah

c. Menyediakan dukungan administratif

d. Mengelola pemeliharaan gedung dan sarana dan prasarana lannya.

Data-data yang masuk berkenaan dengan komponen ini dapat dilihat dari sumber dana, fasilitas madrasah, pembagian tugas madrasah dan program madrasah.

Pada data mengenai sumber dana dan bagaimana dana dialokasikan telah dijelaskan sebelumnya. Ada lima sumber dana yang menjadi andalan MTsN Batusangkar yaitu : wali siswa, mastarakat, donatur tetap wakaf dan bantuan pemerintah. Dari data yang ada ternyata dana dari wali siswa tidak begitu banyak 
menjanjikan karena dari 407 siswa sebagian besar orang tua mereka adalah sebagai buruh sebanyak 253 orang atau sekitar $62,16 \%$, dan sebagai petani ada 66 orang atau $16,61 \%$. Selama ini satu-satunya dana penopang adalah dana Bantuan Operasional Madrasah (BOM) dari Pemda Batusangkar, di samping dari masyarakat da para donatur sehingga pelaksanaan pendidikan dapat berjalan dengan baik. Adapun alokasi dana tersebut untuk operasional madrasah dan pembangunan fisik dengan kegiatan:

1) Kegiatan Belajar Mengajar (KBM) dan pelaksanaan kurikulum

2) Kegiatan kesiswaan

3) Perlengkapan sarana dan prasarana

4) Humas

5) Training tenaga pengajar

Sedangkan untuk dukungan administratif madrasah hanya memiliki 5 orang karyawan, 3 buah komputer, 2 mesin ketik, stensil, telepon masing-masingnya satu unit.

Demikian juga yang berkaitan dengan "pengelolaan dan pemeliharaan sarana dan prasarana" dapat dilihat dari tugas "bagian sarana dan prasarana" yang memiliki 4 tugas yaitu:

1) Inventarisasi barang-barang madrasah

2) Pendayagunaan sarana dan prasarana

3) Pengelolaan keuangan alat-alat pelajaran

Sedangkan yang berhubungan dengan buku-buku perpustakaan serta peralatan laboratorium menjadi tugas masing-masing pengelola.

Selanjutnya pabila dilihat pada komponen keempat ini MTsN Batusangkar termasuk cukup memenuhi, meskipun masih ada kekuranganya namun secara minimal komponen-komponen tersebut telah terpenuhi dengan baik. Dan apabila hal ini dikaji dari tipe/model MBS yang menjadi 3 tipe/model yaitu tipe penuh, menengah dan minimal maka pelaksanaan MBS di MTsN Batusangkar termasuk tipe minimal.

\section{Kontribusi MBS terhadap Peningkatan Kualitas dan Mutu Pendidikan di MTsN Batusangkar}

Data yang menunjukkan bahwa pelaksanaan MBS di MTsN Batusangkar dapat meningkatkan kualitas dan mutu pendidikannya, hal ini dapat dilihat atau dikaji melalui tiga hal penting yaitu :

a. Prestasi akademik

Dari prestasi akademik menunjukkan terjadi peningkatan hasil NEM rata-rata siswa dari tahun 2004/2005 NEM mencapai 5,42, tahun 2005/2006 NEM mencapai 5,72 sedangkan pada tahun 2006/2007 mencapai 6,37. Dengan demikian dapat diartikan bahwa MTsN Batusangkar dapat meningkatkan mutu dan kualitas siswanya dari tahun ketahun.

\section{b. Penampilan organisasi}

Dalam penampilan organisasi ini ada beberapa indikator yang harus dipenuhi yaitu:

1) Rencana pelajaran

2) Proyek bersama

3) Kurikulum baru

4) Semangat belajar

5) Pembelajaran

6) Pertemuan orang tua

7) Prestasi atletik

8) Program seni dan musik

9) Aktivitas kelas.

Berdasarkan data di lapangan menunjukkan bahwa MTsN Batusangkar telah banyak meraih berbagai prestasi yang berkaitan dengan hal di atas, baik prestasi di bidang kesenian maupun olah raga. Selengkapnya dapat dilihat pada prestasi non akademik tiga tahun terakhir.

c. Kepuasan kerja

Sebagai acuan kepuasan kerja adalah hasil angket sebagaimana yang telah dibahas pada bab III yaitu hasilnya menunjukkan sebagai berikut:

1) Perasaan senang dalam bekerja

\begin{tabular}{c|c|c|c|c}
\hline Jumlah & $\begin{array}{c}\text { Sangat } \\
\text { Responden }\end{array}$ & $\begin{array}{c}\text { Cukup } \\
\text { Senang }\end{array}$ & Biasa & $\begin{array}{c}\text { Kurang } \\
\text { Senang }\end{array}$ \\
\hline
\end{tabular}




\begin{tabular}{c|c|c|c|c}
\hline 24 & 7 & 15 & 2 & - \\
\hline $100 \%$ & $29,17 \%$ & $26,50 \%$ & $8,33 \%$ & - \\
\hline
\end{tabular}

2) Perasaan puas dalam bekerja

\begin{tabular}{c|c|c|c|c}
\hline $\begin{array}{c}\text { Jumlah } \\
\text { Responden }\end{array}$ & $\begin{array}{c}\text { Sangat } \\
\text { puas }\end{array}$ & $\begin{array}{c}\text { Cukup } \\
\text { puas }\end{array}$ & Biasa & $\begin{array}{c}\text { Kurang } \\
\text { puas }\end{array}$ \\
\hline 24 & 7 & 14 & 3 & 5 \\
\hline $100 \%$ & $29,17 \%$ & $58,33 \%$ & $12,50 \%$ & $20,63 \%$ \\
\hline
\end{tabular}

Setelah diadakan cek ulang data tersebut dengan wawancara ternyata kekurangpuasan mereka dalam bekerja yang mencapai $20,63 \%$ responden adalah ketidakpuasan terhadap hasil yang dicapai oleh madrasah selama ini, ini semestinya masih bisa ditingkatkan lagi. Adapun sebagian lagi menyatakan cukup puas sebanyak 58,33 \% karena menurut responden memang itu telah pantas dihasilkan mengingat berbagai macam keterbatasan yang dimiliki oleh madrasah.

Dengan demikian jika keberhasilan organisasi ditinjau dari kepuasan kerja maka MTsN Batusangkar dikatakan sudah cuup berhasil. Hal ini ditandai dengan $29,17 \%$ yang mengatakan sangat senang, $29,17 \%$ juga mengatakan sangat puas, 62,50\% mengatakan cukup senang, 58,33\% mengatakan cukup puas, $8,33 \%$ dan $12,50 \%$ mengatakan biasa saja dan tak seorangpun yang mengatakan kurang senang, serta hanya 20,63\% yang mengatakan kurang puas dengan alasan tertentu.

\section{SIMPULAN}

Berdasarkan pada paparan data dan analisa serta landasan teori yang ada, maka keseluruhan itu dapat disarikan dalam bentuk kesimpulan sebagai berikut:

1. MTsN Batusangkar telah melaksanakan MBS dengan cukup baik. Hal ini terbukti dari beberapa karakteristik MBS baik dari segi manajemen, PBM, SDM, sumber dana dan administrasi telah dilaksanakan dengan baik meskipun secara sederhana.

2. Manajemen MTsN Batusangkar juga telah cukup berhasil memberikan kontribusi terhadap output/ outcomenya, hal ini terbukti secara bertahap mampu menigkatkan prestasi siswa, kepuasan kerja guru dan karyawan serta memiliki penampilan organisasi yang cukup baik.

3. Faktor pendukung dalam pelaksanaan MBS di MTsN Batusangkar antara lain adalah kepemimpinan yang kaharismatik dan dukungan masyarakat, pemerintah yang cukup tinggi. Sedangkan faktor penghambatnya adalah input siswa yang masih rendah, keterbatasan sarana dan prasarana, sumber dana dari para orang tua siswa yang kurang menjanjikan disebabkan mayoritas mereka adalah berprofesi sebagai buruh.

\section{DAFTAR RUJUKAN}

Asnawir, Manajemen Pendidikan, 2006. Padang: IAIN IB Press

Ainurrofiq, 1998. Tesis: Manajemen dalam Pendidikan Islam: Telaah atas Fungsifungsi Manajemen, Padang: IAIN Pascasarjana

B. Suryosubroto, 2004. Manjemen Pendidikan Sekolah, Jakarta: Rineka Cipta

Depi Asmal, 2003. Tesis: Kebijakan Pemerintah ORBA tentang Pendidikan Islam:Implikasinya terhadap Sistem Pendidikan Madrasah dan Pembaharuannya Pasca ORBA, Padang: IAIN Pascasarjana

Depag RI, 2005. Pedoman Manajemen Berbasis Madrasah, Jakarta: Dirjen Kelembagaan Agama Islam

E. Mulyasa, 2002. Manajemen Berbasis Sekolah, Bandung: Rosdakarya

Hadari Nawawi, 1993. Kepemimpinan Menurut Islam, Yogyakarta: Gadjah Mada Unuversity Press

Imam Tholkhah, 1988. Manajemen Madrasah Aliyah, Jakarta: Direktul Jenderal Bimbaga Islam Departemen Agama RI

Nasution, 1988. Metode Penelitian Naturalistik kualitatif,Bandung: Tarsito

Nawwal Ath-Thuwairaqi, 2004. Sekolah Unggulan berbasis Sirah Nabawiyah, Jakarta : Darul Falah

S. Nasution, 1992. Metode Penelitian Naturalistik, Bandung: Tarsiti 
Sakdullah, 2002. Konsep Strategi Pembelajaran di Madrasah Aliyah Gajah Demak, Tesis Pascasarjana IAIN Walisongo, Semarang

Sanapiah Faisal, 1990. Penelitian Kualitatif, Dasar-dasar dan Aplikasi, Malang: Yayasan Asih Asah Asuh

Suharsimi Arikunto, 1998. Prosedur Penelitian Suatu Pendekatan Praktek, Jakarta: PT. Rineka Cipta

Undang-undang RI Nomor: 20 Tahun 2003, pasal 51 ayat 1: Pengelolaan satuan anak usia dini, pendidikan dasar dan pendidikan menengah dilaksanakan berdasarkan pelayanan minimal dengan prinsip manajemen berbasis sekolah/madrasah.
Utoyo Dimyati, 2004. MBS dalam Upaya Peningkatan Mutu Madrasah (Studi Kasus di Madrasah Aliyah Banat NU Kudus). Tesis Pascasarjana IAIN Walisongo Semarang

Yunahar Ilyas, et. al, 1993. Muhammadiyah dan $N U$ (Reorientasi wawasan Keislaman), Yogyakarta: LPPI UMY 